\title{
Meslek Yüksekokulu Öğrencilerinin Sosyal Ă̆ Sitesi Kullanım Alışkanlıklarının Kişilik Özellikleri İle İlişkisi*
}

\author{
Demet Ünalan ${ }^{1} \quad$ Mustafa Baştürk ${ }^{2} \quad$ Sinem Somunoğlu İkinci ${ }^{3} \quad$ Ayşegül Aydın ${ }^{4}$ \\ ${ }^{1,4}$ Erciyes Üniversitesi Halil Bayraktar Sağlık Hizmetleri Meslek Yüksekokulu, Kayseri/ TÜRKIYYE \\ ${ }^{2}$ Erciyes Üniversitesi Tıp Fakültesi Psikiyatri Anabilimdal, Kayseri/TÜRKIYYE \\ ${ }^{3}$ Uludă̆ Üniversitesi Să̆lık Hizmetleri Meslek Yüksekokulu, Bursa/TÜRKIYE \\ E-mail: ssomunoglu@yahoo.com
}

\begin{abstract}
Özet
Amaç: Bu çalışmanın amacı Meslek Yüksekokulu öğrencilerinin sosyal ağ sitelerini kullanım amaçlarını incelemek ve kişilik özellikleri ile sosyal ağ sitesi kullanım amacı arasındaki ilişkiyi araştırmaktır.
\end{abstract}

Yöntem: Kesitsel tipteki bu çalışma, 02-31 Ocak 2017 tarihleri arasında Erciyes Üniversitesi Sağlık Hizmetleri Meslek Yüksekokulu'nda bulunan 10 farklı programda öğrenim gören ve aktif olarak bir sosyal ağ sitesini kullanan 300 öğrenci üzerinde yürütülmüştür. Veri toplama aracı olarak öğrencilerin demografik ve sosyo-kültürel özellikleri ile sosyal ağları kullanma durumlarını yansıtan bir anket formu, Sosyal Ağ Siteleri Kullanım Amacı Ölçeği ve Beş Faktör Kişilik Ölçeği kullanılmıştır. Araştırma verilerinin istatistiksel analizinde Student t testi ve Varyans Analizi uygulanmış, değişkenler arasındaki ilişkinin değerlendirilmesinde ise Pearson Korelasyon Katsayısı hesaplanmıştır.

Bulgular: Öğrencilerin sosyal ağ sitelerini en çok sosyal etkileşim ve iletişim amaçlı kullanırken, en az eğitim amaçlı kullandıkları tespit edilmiştir. Öğrencilerin Beş Faktör Kişilik Ölçeği ve Sosyal Ăg Siteleri Kullanım Amacı Ölçeği alt boyut puanları arasındaki ilişki incelendiğinde; dışadönük ve gelişime açık kişilik özelliği puanları ile sosyal etkileşim ve iletişım, tanıma ve tanınma amaçlı kullanım, eğitim amaçlı kullanım sosyal ağ siteleri kullanımı alt boyutlarında ve Sosyal Ağ Siteleri Kullanım Amacı Ölçek toplam puanları arasında zayıf düzeyde pozitif yönde anlamlı ilişki bulunmuştur $(\mathrm{p}<0,05)$.

Sonuç: Öğrencilerin sosyal ağ sitelerini eğitim amaçlı kullanımlarının özendirilmesi ve zamanlarını etkin bir şekilde yönetmeleri konusunda bilinçlendirilmeleri önemlidir.

Anahtar Kelimeler: Sosyal ağ sitesi, öğrenci, kişilik özelliği.

\begin{abstract}
Objective: The objective of this study is to search about the social network usage aims of Vocational School students and to investigate the relationship between personality traits and social network usage.

Method: This cross-sectional study was conducted on 300 students studying at 10 different programmes at Erciyes University Health Services Vocational School and using a social network actively between the dates of 02-31 January 2017. A questionnaire form reflecting the
\end{abstract}

\footnotetext{
* 29 Haziran - 1 Temmuz 2017 tarihleri arasında Aydın Adnan Menderes Üniversitesi tarafından düzenlenen 1. Uluslararas1 Sağlık Bilimleri Kongresi'nde sözel bildiri olarak sunulmuştur.
} 
demographic and socio-cultural characteristics of the students together with their state of using social networks, Social Network Objective Scale and Five Factor Personality Scale were used as data collection tools. Student $\mathrm{t}$ test and Analysis of Variance were practiced in statistical analysis of the data, and Pearson Correlation Coefficient was calculated to evaluate the relationship between the variables.

Findings: It was determined that while students used social networks for social interaction and communication most, they used them for the purpose of education least. When the relation between Five Factor Personality Scale and Social Network Objective Scales were investigated, it was found a low positive significant relationship between the extroverted and open for improvement personality traits scores and the social network usage sub-dimensions of social interaction and communication, usage with the aim of getting to know and getting to be known, usage for educational purposes and Social Network Usage Objective Scale total scores $(\mathrm{p}<0.05)$.

Conclusion: It is important that students are encouraged to use social networking sites for educational purposes and raised awareness about managing their time effectively.

Key Words: Social network, student, personality trait.

\section{Giriş}

Teknolojinin geçirmiş olduğu hızlı değişim (Aslanyürek ve diğerleri, 2015, Diker ve Uçar, 2017, Karlı, 2010, Kaya ve diğerleri, 2015, Tektaş, 2014), mobil uygulamaların günlük hayatımızın ayrılmaz bir parçası olması (Karl1, 2010, Kaya ve diğerleri, 2015) ve sosyal medyanın iletişimde üstlendiği önemli rol teknolojiye her an ulaşma isteğini de beraberinde getirmiştir (Aslanyürek ve diğerleri, 2015). Internet kullanımı özellikle 1990'lı y1llardan itibaren giderek artış göstermiş ve 2000'li yıllara gelindiğinde de sosyal medya her kesimden birçok insanın ilgi odağı haline gelmiştir (Aslanyürek ve diğerleri, 2015, Kaya ve diğerleri, 2015, Tektaş, 2014). Sosyal medya araçları bireylere bilgi edinme, eğitimi destekleme, gündemi takip etme, iletişim kurma, görsel içerikli birtakım dosyalara ulaşma ve fikirlerini açıklayabilme imkânı sunmakta, bu durum sosyal medya araçlarının yaygın bir kullanıma sahip olmasına neden olmaktadır (Aslanyürek ve diğerleri, 2015).

Sosyal medya araçlarının kullanıcıların içerik oluşturarak katkıda bulunması, içeriklere ilişkin bağlantı eklenebilmesi, içeriklerin aktif ya da pasif kullanım yolu ile değerlendirilebilmesi ve kullanıcıların ortak ilgi alanlarına göre bazı sosyal ağlar oluşturabilmesi gibi birtakım özellikleri bulunmaktadır. Sosyal medya araçlarının sınıflandırılmasına ilişkin olarak da çeşitli yaklaşımlar geliştirilmiş olup, yapılan en yaygın sınıflandırma bloglar, wikiler, sosyal işaretleme, medya paylaşım siteleri ve sosyal ağlar şeklinde olanıdır (Aslanyürek ve diğerleri, 2015). Bunun dışında sosyal medya araçlarının Eposta grupları, bloglar, forumlar, kurumsal intranet, extranet, hızlı mesaj servisleri ve sosyal ağ siteleri gibi başlıca yedi grupta toplanarak sınıflandırılması da mümkündür (Özdemir ve diğerleri, 2014).

Sosyal medya araçları içerisinde önemli bir yer tutan sosyal ağlar internet ortamında her düzeyden kullanıcının kendini tanımlayarak, sosyal yaşamda sıklıkla kullanılan jest ve mimikleri sanal ortamda çeşitli sembollerle ifade ettiği ve sosyal iletişim kurma ve geliştirme imkânı yakaladığı ortamlar olarak ifade edilmektedir (Işıktaş, 2016, Söğüt ve diğerleri, 2016, Tektaş, 2014). Sosyal ağların kullanımının artmasına bağlı olarak bireylerin sosyalliğinin ölçülebilmesine yönelik birtakım çalışmaların da artış gösterdiği ifade edilmektedir (Dilmen ve Öğüt, 2010, Iş1ktaş, 2016, Söğüt ve diğerleri, 2016). Sosyal medyanın taşıdığı bu özellikler son zamanlarda özellikle eğitimcilerin de dikkatini çekmiş̧ir. Bu nedenle eğitimde iletişimin ve işbirlikçi bir ortamın geliştirilmesi, aktif katılımın sağlanması, kaynak, bilgi ve becerilerin paylaşılması gibi konularda sosyal ağların etkisinin ve kullanıcıların özelliklerinin belirlenmesine yönelik çeşitli çalışmalara ağırlık verilmiştir (Işıktaş, 2016).

$\mathrm{Bu}$ düşünceler çerçevesinde yapılan araştırmada günümüzde yaygın bir kullanıma sahip olan sosyal ağların meslek yüksekokulu öğrencileri tarafından kullanım amaçlarının incelenmesi ve öğrencilerin kişilik özellikleri ile sosyal ağları kullanma amaçları arasındaki ilişkinin saptanması amaçlanmıştır. 


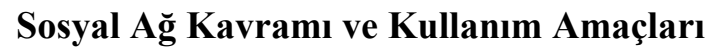

Sosyal ağ kavramı Barnes tarafından ilk kez 1954 yılında kullanılmış olup, bireyin çevresindeki diğer insanlar ile kurduğu ilişkiler şeklinde açıklanmıştır (Bilen ve diğerleri, 2014). Sosyal ağlar genel anlamda kullanıcıların varlığı ile şekillenen yani kullanıcıların katılımı ve ekledikleri içerik ile oluşturulan siteler şeklinde tanımlanmaktadır (Işıktaş, 2016). Bir grup insanın sosyal teknolojilerin varlığ1 sayesinde kullanmış olduğu etkinliklerin bütünü de sosyal ağ olarak ifade edilmektedir (Gülbahar ve diğerleri, 2017). Diğer bir tanıma göre de, sosyal ağ internet üzerinde oluşturulan toplulukların birbirleri ile duygularını, düşüncelerini paylaştıkları ve iletişim kurdukları ağ olarak tanımlanmakta ve bu amaçla kurulan ilişkilerin bütününü kapsamaktadır (Söğüt ve diğerleri, 2016).

Sosyal ağlar içerisinde ön plana çıkan Facebook, Myspace ve Twitter gibi çeşitli siteler sayesinde kullanıcılar kullanıcı adı almakta, profil oluşturabilmekte, kendilerini tanıtmakta, kişisel bilgilerini, fotoğraflarını ve videolarını paylaşmakta, mesaj alıp gönderebilmekte ve yeni insanlar tanıma imkânı bulmaktadır. Görüldüğü gibi sosyal ağ siteleri sayesinde bireylerin farklı düzeylerdeki gereksinimlerinin karşılanması mümkün olmaktadır (Söğüt ve diğerleri, 2016). Bununla birlikte sosyal paylaşım ağlarının ticari alanda müşteri ile ilişkilerin iyileştirilmesi, ürün geliştirme sürecinde tüketicinin fikirlerinin öğrenilmesi, bireylerin gerçek hayatta olmak isteyip de olamadıkları yazar, fikir beyan eden kişi gibi belirli rolleri üstlenmeleri, pasif konumdan aktif konuma geçebilmeleri (Karlı, 2010), reklam ve halkla ilişkiler uygulamalarının gerçekleştirilmesi, sosyal yaşam ve kariyer firsatları sunması gibi çeşitli amaçlar ile de kullanıldıkları görülmektedir (Özdemir ve diğerleri, 2010).

Hegel (1997) yapmış olduğu çalışmasında sosyal ağ sitelerinin kullanım amaçlarının bilgi paylaşım toplulukları, ilgi toplulukları, eğlence toplulukları, ilişki toplulukları ve tartışma toplulukları şeklinde başlıca beş grup halinde sınıflandırılmasının mümkün olacağını ifade etmektedir (Aktaran Özdemir ve diğerleri, 2010).

Özellikle üniversite öğrencileri tarafından sosyal ağ sitelerinin daha çok tercih edildiği gerçeği öğrencilerin hangi amaçla ve ne tür gereksinimlerini karşılamak için sosyal ağ sitelerine yöneldikleri sorusunu da beraberinde getirmiştir. Bununla birlikte sosyal ağ sitelerinin öğrencilerin akademik başarısı, moral ve motivasyonu ve kurdukları iletişimin düzeyi gibi çeşitli değişkenler üzerinde de etkili olması bu yönde sürdürülen çalışmaların artarak devam etmesine yol açmıştır. Bu çalışmalar sayesinde sosyal ağ sitelerinin kullanım amaçlarının ve bireyleri bu siteleri kullanmaya iten nedenlerin belirlenmesinin ve eğitsel amaçlı kullanımda nelere dikkat edilmesi gerektiğinin saptanmasının mümkün olacağı düşünülmektedir (Söğüt ve diğerleri, 2016). Bununla birlikte literatürde yapılan çalışmalar incelendiğinde sosyal ağ sitesi kullanım alışkanlıkları ile kullanıcıların kişilik (mi, kişilik mi) özellikleri arasındaki ilişkinin belirlenmesine yönelik çalışmaların da yer aldığı görülmektedir. Bu çalışmaların bireylerin dışadönüklükleri, duygusal denge durumları, deneyimlere açıklık, uyumluluk ve sorumluluk gibi çeşitli kişilik özellikleri açısından değerlendirilmesine ve kişilik özelliklerinin tahmin edilerek gerekli düzenlemelerin yapılmasına yönelik katkı sağlayacağı ifade edilmektedir (Dal ve Dal, 2014).

\section{Gereç ve Yöntem}

Kesitsel tipteki bu çalışma 02-31 Ocak 2017 tarihleri arasında Erciyes Üniversitesi Sağlık Hizmetleri Meslek Yüksekokulu'nda 10 farklı programda öğrenim gören ve aktif olarak bir sosyal ağ sitesi kullanan öğrencileri kapsamaktadır. Çalışma 2016-2017 Eğitim-Öğretim Yılı'nda kayıt yaptıran ve eğitim-öğretime devam eden 600 öğrenciden $1 / 2$ basit tesadüfí örnekleme yöntemi ile seçilen 300 öğrenci üzerinde yapılmıştır. Araştırmanın yapıldığı tarihlerde okula gelmeme, kayıt dondurma ve araştırmaya katılmayı kabul etmeme gibi nedenlere bağlı olarak araştırma $271(\% 90,3)$ öğrenci üzerinde yürütülmüștür.

Araştırmada veri toplama aracı olarak; öğrencilerin yaşı, cinsiyeti, geliri, geldiği şehir, kaldığı yer, sigara, alkol kullanma durumu, mezun olduğu lise gibi demografik ve sosyo-kültürel özelliklerine ilişkin sorular ile internette bir günde ortalama ne kadar zaman geçirdiği, sosyal ağ sitelerinde üyeliğinin olup olmadığı, hangi sosyal ağ sitelerine üye olduğu ve üyelik süresi, sosyal ağ sitelerindeki hesaplarına hangi sıklıkla giriş yaptığı, en çok zaman geçirdiği sosyal ağ sitesinin hangisi olduğu, en çok zaman geçirdiği sosyal ağ sitesinde tek oturumda genellikle ortalama ne kadar zaman harcadığı, 
sosyal ağ sitelerine bağlanmak için en çok hangi araçları tercih ettiği, sosyal ağ sitelerine en çok hangi ortamlardan bağlandığ 1 ile ilgili bilgileri içeren anket formu ile Sosyal A $\breve{g}$ Siteleri Kullanım Amacı Ölçeği ve Beş Faktör Kişilik Ölçeği (BFKÖ) kullanılmıştır.

Sosyal Ağ Siteleri Kullanım Amacı Ölçeği Karal ve Kokoç (2010) tarafindan geliştirilen ve 14 maddeden oluşan bir ölçektir. Likert tipi ölçekteki maddeler "1=Kesinlikle Katılmıyorum" ve " $5=$ Kesinlikle Katılıyorum" arasında birden beşe kadar her bir madde değerlendirilmekte ve ölçekten elde edilen puanlar 14 ile 70 puan aralığında yer almaktadır. Ölçek; sosyal etkileşim-iletişim amaçlı kullanım, tanıma-tanınma amaçlı kullanım ve eğitim amaçlı kullanım olmak üzere üç alt boyuttan oluşmaktadır. Ölçeği Cronbach’s Alpha $(\alpha)$ değeri 0,838 olarak hesaplanmıştır.

BFKÖ ise; Benet-Martinez ve John (1998) tarafından geliştirilen, Sümer, Lajunen ve Özkan tarafından Türkçeye çevrilen, özbildirim tarzı, 5'li Likert tipi (1=Hiç Katılmıyorum, 5=Tamamen Katılıyorum), 44 maddelik bir ölçme aracıdır. Ölçek kişilik özelliklerini Gelişime Açıklık (10 madde), Uyumluluk (9 madde), Özdisiplin (9 madde), Dışadönüklük (8 madde) ve Nörotiklik (8 madde) olmak üzere beş faktör olarak ve her bir boyutta yer alan farklı sayıdaki ifadeler ile ölçmektedir (Sümer ve diğerleri, 2005). Ölçekten alınan yüksek puanlar ilgili boyuta olan eğilimin arttığını göstermektedir. Ölçeğin Cronbach's Alpha $(\alpha)$ değeri 0,732 olup, "Gelişime açıklık” faktörü için Cronbach's Alpha $(\alpha)$ değeri 0,716, "Özdisiplin" faktörü için 0,618, "Dişadönüklük" faktörü için 0,694, "Uyumluluk" faktörü için 0,622 ve "Nörotiklik" faktörü için de 0,60 olarak hesaplanmıştır.

Verilerin analizi R 3.2.0 (www.r-project.org) yazılımında gerçekleştirilmiştir. Gruplar aras1 karşılaştırmalarda nicel değişkenler için bağımsız gruplar arasında Student $t$ testi ve tek yönlü Varyans Analizi uygulanmıştır. Çoklu karşılaştırma analizi olarak (post-hoc test) Tukey yöntemi kullanılmıştır. Değişkenler arasındaki ilişki ise, Pearson Korelasyon Katsayısı kullanılarak hesaplanmıştır. Değerlendirmelerde anlamlılık düzeyi $\mathrm{p}<0,05$ kabul edilmiştir.

\section{Bulgular}

Araştırma grubunu oluşturan öğrencilerin \%81,2'si 18-20 yaş grubunda olup, \%71,2'si kız öğrenci, $\% 42,1$ 'i sağlık meslek lisesi mezunu, \%32,1'i öğrenim için Kayseri dışındaki bir şehirden gelmiş, $\% 68,6$ 'sı aile ile birlikte aynı evde yaşamakta ve \%11,1'i de gelir getirici bir işte çalışmaktadır. Öğrencilerin \%54,6'sının annesi ilkokul mezunu, \%88,6'sının annesi ev hanımı, \%35,1'inin babas1 ilkokul mezunu ve \%25,6'sının babası serbest meslek sahibidir. Öğrenci ailelerinin aylık gelir ortancas1 2000 TL (550-10.000) olup, öğrencilerin \%20,7'si sigara içmekte, \%1,8'i ise alkol kullanmaktadır.

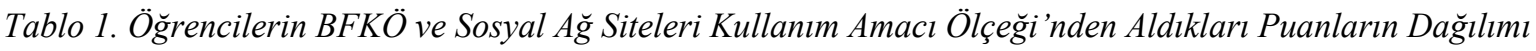

\begin{tabular}{|c|c|}
\hline Ölçekler & $\mathbf{X} \pm \mathbf{S D}$ \\
\hline \multicolumn{2}{|l|}{ Beş Faktör Kişilik Ölçeği } \\
\hline Nörotiklik & \multirow{5}{*}{$\begin{array}{l}22,6 \pm 5,0 \\
27,2 \pm 5,0 \\
34,7 \pm 5,7 \\
32,5 \pm 4,2 \\
31,9 \pm 4,5\end{array}$} \\
\hline Dişadönük & \\
\hline Gelişime açık & \\
\hline Uyumluluk & \\
\hline Özdisiplin & \\
\hline \multicolumn{2}{|l|}{ Sosyal Ağ Siteleri Kullanım Amacı Ölçeği Alt Boyutu } \\
\hline Sosyal etkileşim ve iletişim amaçlı kullanım & \multirow{4}{*}{$\begin{array}{c}25,0 \pm 6,0 \\
10,5 \pm 3,1 \\
9,1 \pm 2,9 \\
44,5 \pm 10,3\end{array}$} \\
\hline Tanıma ve tanınma amaçlı kullanım & \\
\hline Eğitim amaçlı kullanım & \\
\hline Sosyal Ağ Siteleri Kullanım Amacı Ölceği Toplam Puanı & \\
\hline
\end{tabular}

Öğrenciler, BFKÖ'nin alt ölçeklerinden en yüksek puanı gelişime açık kişilik özelliğinden, en düşük puanı Nörotiklik kişilik özelliğinden almışlardır. Öğrencilerin, sosyal ağ sitelerini en çok sosyal etkileşim ve iletişim amaçlı kullanırken, en az eğitim amaçlı kullandıkları tespit edilmiştir (Tablo 1). 


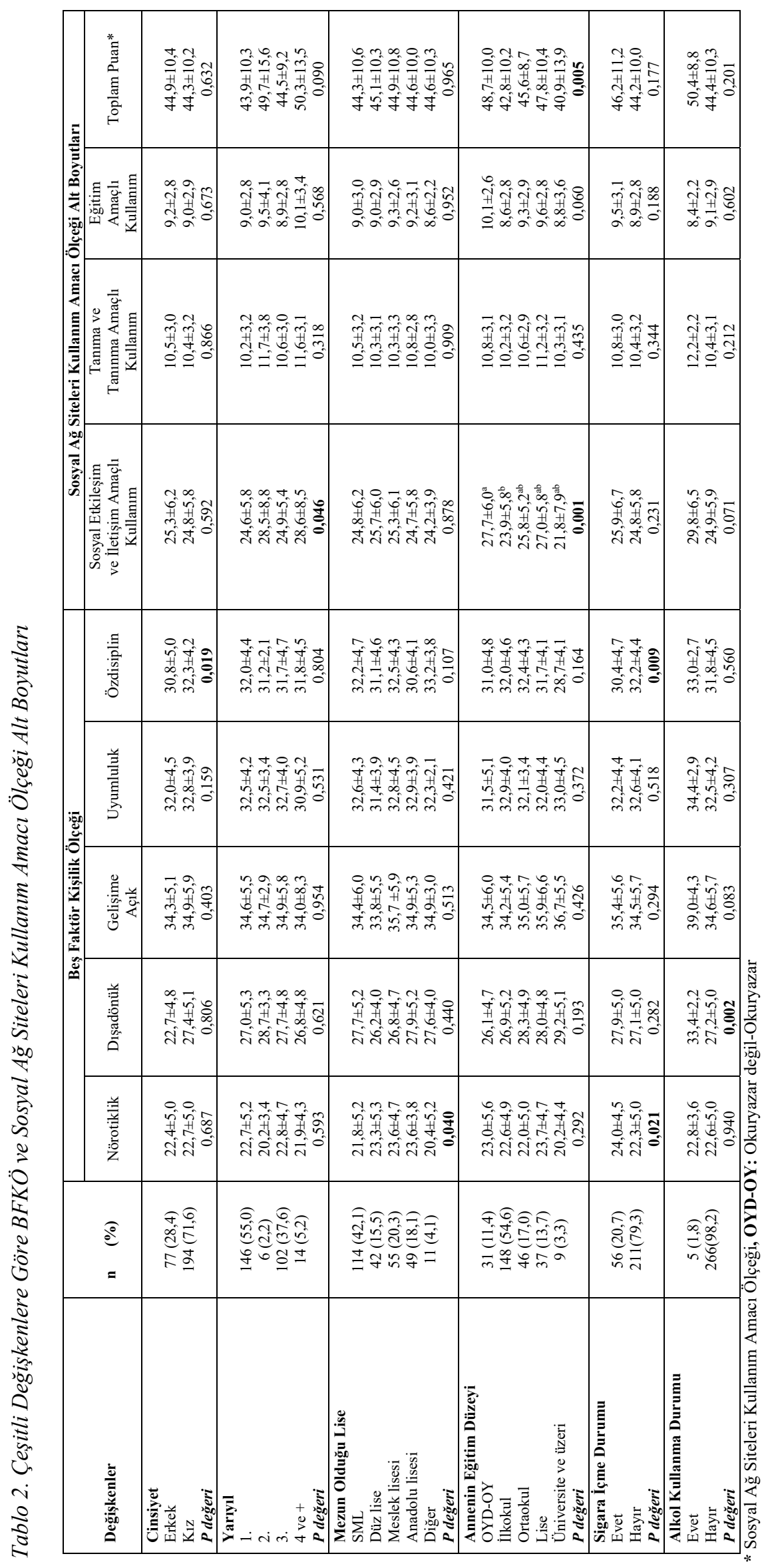


Öğrencilerin cinsiyete göre BFKÖ ve Sosyal Ağ Siteleri Kullanım Amacı Ölçek alt boyutları karşılaştırıldığında, kız öğrencilerin Özdisiplin kişilik özelliği puanları anlamlı düzeyde yüksek bulunmuştur $(\mathrm{p}<0,05)$ (Tablo 2).

Dört ve daha ileri öğrenim döneminde olan öğrenciler, Sosyal Ağ Siteleri Kullanım Amacı Ölçeğinin Sosyal Etkileşim ve İletişim Amaçlı Kullanım alt boyutundan anlamlı düzeyde yüksek puan almışlardır $(p<0,05)$ (Tablo 2). Diğer liselerden mezun olan öğrencilerin BFKÖ'nin nörotiklik boyutu puanları anlamlı düzeyde düşük bulunmuştur $(\mathrm{p}<0,05)$ (Tablo 2).

Annenin öğrenim durumuna göre BFKÖ ve Sosyal Ağ Siteleri Kullanım Amacı Ölçek alt boyutları karşılaştırıldığında, Sosyal Etkileşim ve İletişim Amaçlı Kullanım alt boyutunda ve Sosyal Ağ Siteleri Kullanım Amacı Ölçeği toplam puanlarında gruplar arasındaki fark istatistiksel açıdan anlamlı bulunmuştur $(p<0,05)$. Bu farklılık Sosyal Etkileşim ve İletişim Amaçlı Kullanım alt boyutunda OYDOY ile ilkokul ve ilkokul mezunları ile lise mezunlarından kaynaklanmaktadır. Sosyal A $\breve{g}$ Siteleri Kullanım Amacı Ölçeği toplam puanlarında gruplar arasındaki farklılık OYD-OY ve ilkokul mezunlarından kaynaklanmaktadır (Tablo 2).

Sigara içmeyen öğrencilerin Nörotiklik ve Özdisiplin kişilik özelliği puanları anlamlı düzeyde yüksek bulunmuştur $(\mathrm{p}<0,05)$ (Tablo 2). Alkol kullanan öğrencilerin dişadönük kişilik özelliği puanları anlamlı düzeyde yüksek bulunmuştur $(\mathrm{p}<0,05)$ (Tablo 2$)$. 


\begin{tabular}{|c|c|c|c|c|c|c|c|}
\hline (a) & 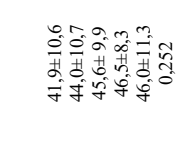 & 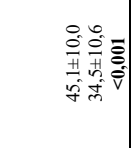 & 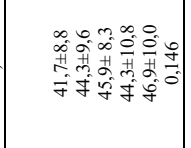 & 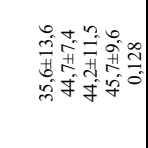 & 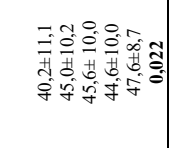 & 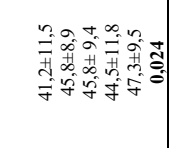 & 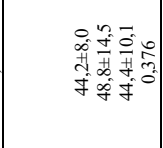 \\
\hline 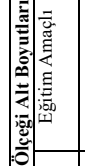 & 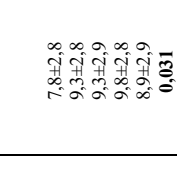 & 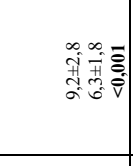 & 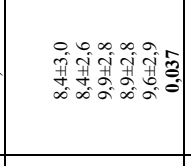 & 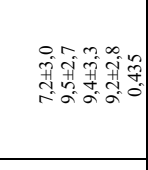 & 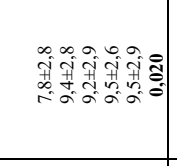 & 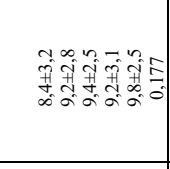 & 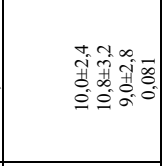 \\
\hline 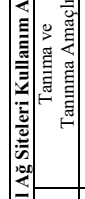 & 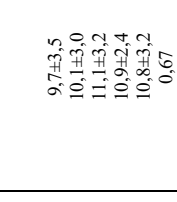 & 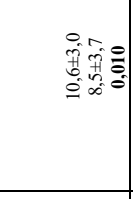 & 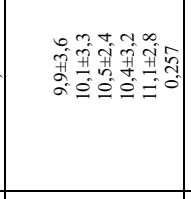 & 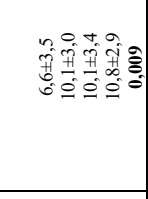 & 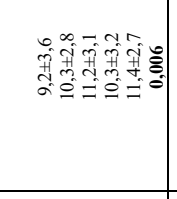 & 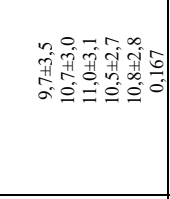 & 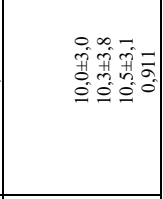 \\
\hline 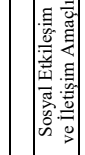 & 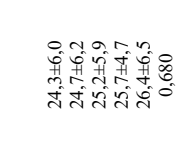 & 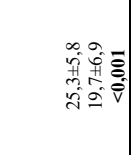 & 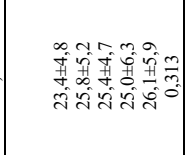 & 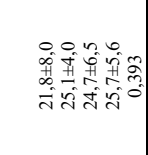 & 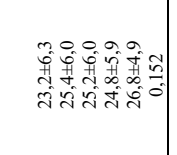 & 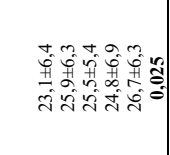 & 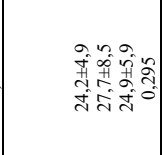 \\
\hline 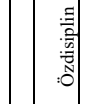 & 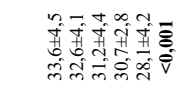 & 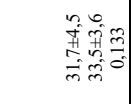 & 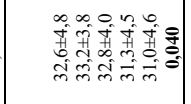 & 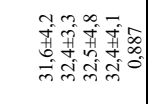 & 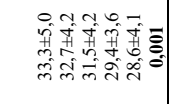 & 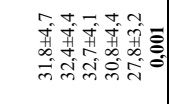 & 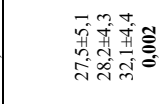 \\
\hline 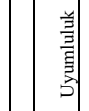 & 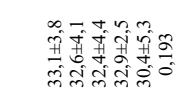 & 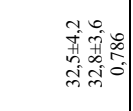 & 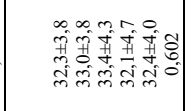 & 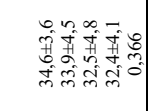 & 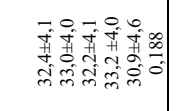 & 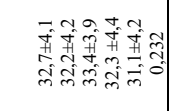 & 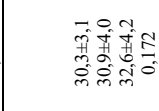 \\
\hline $\mid$ & 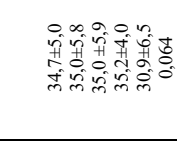 & 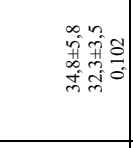 & 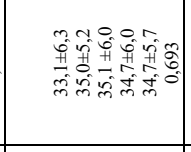 & 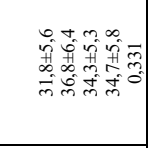 & 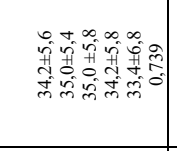 & 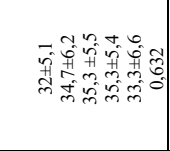 & 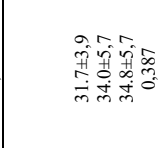 \\
\hline 彦 & 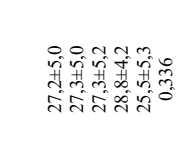 & 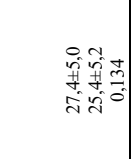 & 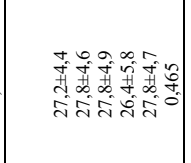 & 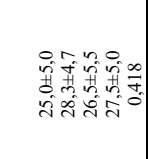 & 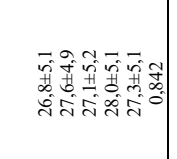 & 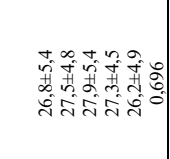 & 군 \\
\hline 慈 & 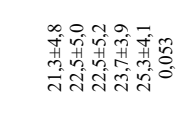 & 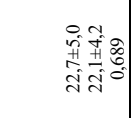 & 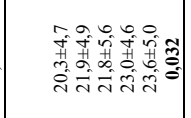 & 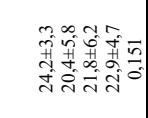 & 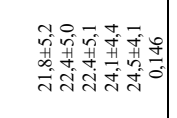 & 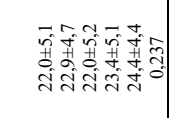 & 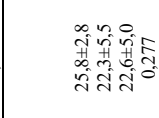 \\
\hline $\begin{array}{l}\underbrace{0} \\
=\end{array}$ & 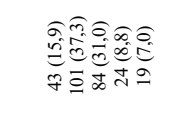 & 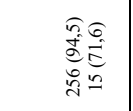 & 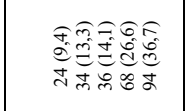 & 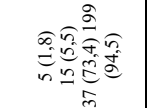 & 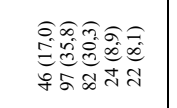 & 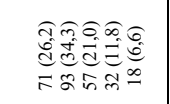 & 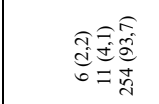 \\
\hline . & 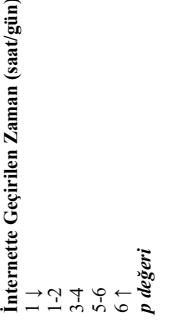 & 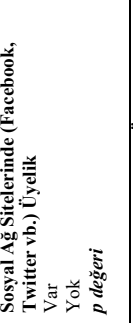 & 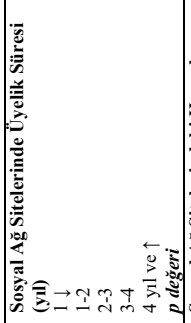 & 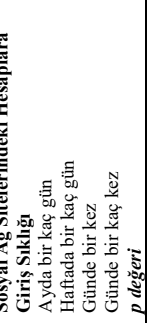 & 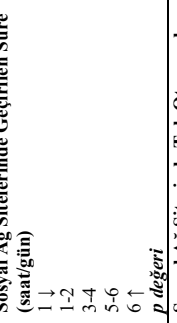 & 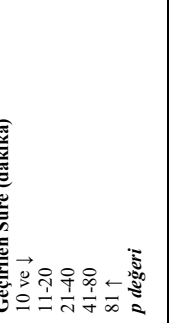 & 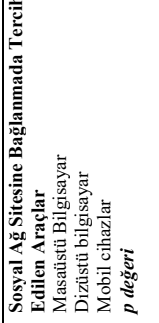 \\
\hline
\end{tabular}


İnternette geçirilen zamana göre BFKÖ ve Sosyal A $\breve{g}$ Siteleri Kullanım Amacı Ölçek alt boyut puanları karşılaştırıldığında, Özdisiplin Kişilik Özelliği ve Eğitim Amacı boyutlarında gruplar arasındaki fark istatistiksel açıdan anlamlı bulunmuştur. Bu farklılık Özdisiplin Kişilik Özelliği boyutunda günde altı saatten fazla internette zaman geçiren öğrenciler ile bir saatten az vakit geçiren öğrencilerden, sosyal ağ sitelerini Eğitim Amaçlı Kullanım alt boyutunda ise, günde bir saatten az internette zaman geçiren öğrenciler ile bir-iki saat ve beş-altı saat geçiren öğrencilerden kaynaklanmaktadır $(\mathrm{p}<0,05)$ (Tablo 3$)$.

Öğrencilerin \%94,5'inin sosyal ağ sitelerini kullandığı, \%36,7'inin dört y1l ve daha uzun süredir üyeliği olduğu, \%79,0'ının Instagram'a, \%60,9'unun Facebook'a, \%36,9'unun da Snapchat'e üye oldukları tespit edilmiştir. Sosyal ağ sitelerinde üyelik süresine göre BFKÖ ve Sosyal A $\breve{g}$ Siteleri Kullanım Amacı Ölçek alt boyut puanları karşılaştırıldığında, Nörotiklik Kişilik Özelliği, Özdisiplin ve Eğitim Amaçlı Kullanım alt boyutlarında gruplar arasındaki fark istatistiksel açıdan anlamlı bulunmuştur. $\mathrm{Bu}$ farklılık Nörotiklik Kişilik Özellikleri boyutunda üyelik süresi bir yıldan az olan öğrenciler ile dört yıl ve daha fazla olanlardan kaynaklanmaktadır $(\mathrm{p}<0,05)$ (Tablo 3). Sosyal ăg sitelerinde (Facebook, Twitter, Friendfeed gibi) üyeliği olan öğrencilerin Sosyal A ̆g Siteleri Kullanım Amacı Ölçeği alt boyut ve toplam puanları anlamlı düzeyde yüksek bulunmuştur $(\mathrm{p}<0,05)$ (Tablo 3$)$.

Sosyal ağ sitelerindeki hesaplara giriş sıklığına göre BFKÖ ve Sosyal Ağ Siteleri Kullanım Amacı Ölçek alt boyut puanları karşılaştırıldığında, Tanıma ve Tanınma Amaçlı Kullanım alt boyutunda gruplar arasındaki fark anlamlı bulunmuştur. Bu farklılık, sosyal ağ sitelerindeki hesaplarına günde bir kaç giriş yapan öğrencilerle, ayda bir kaç kez giriş yapan öğrencilerden kaynaklanmaktadır $(p<0,05)$ (Tablo 3).

Sosyal ağ sitelerinde geçirilen süreye göre BFKÖ ve Sosyal Ağ Siteleri Kullanım Amacı Ölçek alt boyut puanları karşılaştırıldığında, Özdisiplin Kişilik Özelliği boyutunda, sosyal ağ sitelerinin Tanıma ve Tanınma Amaçlı Kullanımı, Eğitim Amaçlı Kullanımı alt boyutlarında gruplar arasındaki fark istatistiksel açıdan anlamlı bulunmuştur. Bu farklılık Özdisiplin Kişilik Özellikleri boyutunda, sosyal ağ sitelerinde geçirilen süre günde bir saatten az olan öğrenciler ile beş-altı saat ve altı saatten fazla olan öğrencilerden, sosyal ağ sitelerinin Tanıma ve Tanınma Amaçlı kullanım alt boyutunda, sosyal ağ sitelerinde geçirilen süre günde bir saatten az olan öğrenciler ile üç-dört saat geçiren öğrencilerden, Eğitim alt boyutunda sosyal ağ sitelerinde geçirilen süre günde bir saatten az olan öğrenciler ile bir-iki saat geçiren öğrencilerden, Sosyal Ağ Siteleri Kullanım Amacı Ölçek toplam puanlarında ise, sosyal ağ sitelerinde geçirilen süre günde bir saatten az olan öğrencilerle bir-iki saat ve beş-altı saat geçiren öğrencilerden kaynaklanmaktadır $(\mathrm{p}<0,05)$ (Tablo 3).

En çok zaman geçirilen sosyal ağ sitesinde tek oturumda geçirilen ortalama süreye göre BFKÖ ve Sosyal A $\breve{g}$ Siteleri Kullanım Amacı Ölçek alt boyut puanları karşılaştırıldığında gruplar arasındaki fark istatistiksel açıdan anlamlı bulunmuştur. Özdisiplin Kişilik Özelliği boyutunda sosyal ağ sitesinde tek oturumda geçirilen ortalama süre 80 dakikadan fazla olan öğrenciler ile 10 dakika, 11-20 dakika ve 21-40 dakika olan öğrencilerden kaynaklanmaktadır. Sosyal Ağ Siteleri Kullanım Amacı Ölçeği sosyal etki alt boyutunda ve Sosyal A $\breve{g}$ Siteleri Kullanım Amacı Ölçek toplam puanlarında ise, sosyal ağ sitesinde tek oturumda geçirilen ortalama süre 10 dakikadan az olan öğrenciler ile 11-20 dakika olan öğrencilerden kaynaklanmaktadır $(\mathrm{p}<0,05)$ (Tablo 3$)$.

Sosyal ağ sitesine bağlanmada tercih edilen araçlara göre BFKÖ ve Sosyal A $\breve{g}$ Siteleri Kullanım Amacı Ölçek alt boyut puanları karşılaştırıldığında, Özdisiplin Kişilik Özelliği boyutunda gruplar arasındaki fark istatistiksel açıdan anlamlı bulunmuştur. Bu farklılık mobil cihazları (cep telefonu, iPhone, Blackberry gibi) tercih eden öğrenciler ile masaüstü ve dizüstü bilgisayarı tercih eden öğrencilerden kaynaklanmaktadır $(\mathrm{p}<0,05)$ (Tablo 3). Öğrencilerin sosyal ăg sitelerine $\% 60,9$ 'u evlerinden, \%15,9'u yurttan, \%14,0' 1 ise kablosuz ağı olan herhangi bir yerden bağlanmaktadır. 

KİSILIKK ÖZELLIKLERİ İLE İLISSKİSI

\begin{tabular}{|lcccc|}
\hline \multirow{2}{*}{ BFKö } & \multicolumn{3}{c|}{ Sosyal Ă̆ Siteleri Kullanım Amacı Ölçeği } \\
\cline { 2 - 5 } & $\begin{array}{c}\text { Sosyal Etkileşim } \\
\text { ve İletişim Amaçlı } \\
\text { Kullanım }\end{array}$ & $\begin{array}{c}\text { Tanıma ve } \\
\text { Tanınma Amaçlı } \\
\text { Kullanım }\end{array}$ & $\begin{array}{c}\text { Eğitim Amaçlı } \\
\text { Kullanım }\end{array}$ & Toplam Puan* \\
\hline Nörotiklik & 0,024 & 0,089 & 0,004 & 0,042 \\
\hline Dışadönük & $0,190^{* *}$ & $0,224^{* *}$ & $0,146^{*}$ & $0,219^{* *}$ \\
\hline Gelişime açık & $0,130^{*}$ & $0,136^{*}$ & $0,251^{* *}$ & $0,187^{* *}$ \\
\hline Uyumluluk & $-0,017$ & 0,028 & $-0,036$ & $-0,012$ \\
\hline Özdisiplin & 0,001 & $-0,058$ & $-0,097$ & $-0,044$ \\
\hline
\end{tabular}

$* \mathrm{p}<0,05, * * \mathrm{p}<0,01$

Tablo 4. Öğrencilerin BFKÖ ve Sosyal Ă̆ Siteleri Kullanım Amacı Ölçeği Boyut Puanları Arasında Korelasyon Matrisi

Öğrencilerin BFKÖ ve Sosyal Ağ Siteleri Kullanım Amacı Ölçeği alt boyut puanları arasındaki ilişki incelendiğinde, Dışadönük ve Gelişime açık Kişilik Özelliği puanları ile Sosyal Etkileşim ve İletişim, Tanıma ve Tanınma Amaçlı Kullanım, Eğitim Amaçlı Kullanım sosyal ă̆ siteleri kullanımı alt boyutlarında, Sosyal A $\breve{g}$ Siteleri Kullanım Amacı Ölçek toplam puanları arasında zayıf düzeyde pozitif yönde anlamlı ilişki bulunmuştur $(\mathrm{p}<0,05)$ (Tablo 4$)$.

\section{Tartışma}

Yapılan araştırma sonucuna göre Sağlık Hizmetleri Meslek Yüksekokulu öğrencilerinin, BFKÖ'nden en yüksek puanı Gelişime Açık Kişilik özelliğinden, en düşük puanı ise Nörotiklik Kişilik özelliğinden aldıkları görülmektedir. Gelişime Açık Kişilik özelliği puanının yüksek olması, öğrencilerin yeni fikirlere, değişime ve farklı bakış açılarına açık olmaları ve geleneksel bir düşünce yapısına sahip olmamaları şeklinde yorumlanmaktadır. Nörotiklik Kişilik özelliği puanının düşüklüğü de öğrencilerin rahat, sakin, huzurlu ve kaygıdan uzak bir duygusal yapıya sahip olmaları şeklinde açıklanmaktadır. Gelişime Açık Kişilik özelliği puanını sırası ile öğrencilerin Uyumluluk Kişilik özelliği puanının, Özdisiplin Kişilik özelliği puanının ve Dışadönüklük Kişilik özelliği puanının takip ettiği görülmektedir. Uyumluluk Kişilik özelliği puanının yüksek olması; öğrencilerin fedakâr ve yardımsever özelliklerinin gelişmesi olarak yorumlanırken, Özdisiplin Kişilik özelliği puanının yüksek olması da titiz, bireysel sorumluluğu yüksek ve programlı çalışan bir özelliğe sahip olmaları şeklinde açıklanmaktadır. Dışadönüklük puanının yüksekliği ise, öğrencilerin sosyalliğini göstermekte, iletişim kurmayı ve girişken olmayı sevmeleri şeklinde yorumlanmaktadır. Araştırma sonucunda elde edilen bir diğer bulgu da, öğrencilerin, sosyal ağ sitelerini en çok sosyal etkileşim ve iletişim amaçlı kullanırken, en az eğitim amaçlı kullandıkları şeklindedir. Bu açıdan bakıldığında öğrencilerin yenilik, değişim, sosyallik gibi sahip oldukları birtakım kişilik özelliklerinden hareketle daha çok sosyal etkileşim, yeni bakış açıları kazanma, iletişimi geliştirme, yeni insanlar tanıma ve girişken olma eğiliminde oldukları görülmektedir. Öğrencilerin Dışadönük Kişilik özellikleri ve Gelişime Açık Kişilik özellikleri ile sosyal ağ sitelerini Sosyal Etkileşim ve İletişim ve Tanıma ve Tanınma Amaçlı Kullanım alt boyutları arasında da pozitif yönde anlamlı ilişki bulunmuştur. Bu bulgular; öğrencilerin sosyal ă̆ sitelerini kullanım amaçlarının belirlemesi ve kişilik özellikleri ile sosyal ağ sitelerinin kullanım amaçları arasındaki ilişkiyi göstermesi açısından önemlidir.

Öğrencilerin sosyal ağ sitelerini kullanım alışkanlıklarının saptanması ve kişilik özellikleri ile kullanım alışkanlıkları arasındaki ilişkinin belirlenmesi için Mehmet Akif Ersoy Üniversitesi Gölhisar Meslek Yüksekokulu öğrencileri üzerinde yapılan bir diğer araştırma sonucuna göre; sosyal ağ sitelerini daha çok tanıdıkları ile iletişim kurma ve gündeme ilişkin bilgi edinme amaçlı kullandıkları görülmektedir. Araştırma sonucunda elde dilen bir diğer bulgu da öğrencilerden dişadönük ve deneyimlere açık kişilik özelliğine sahip olanların, sosyal ağ sitesi kullanıcısı olduğu yönündedir (Dal ve Dal, 2014). 
Sosyal ağ sitelerini kullananların kişilik özeliklerinin belirlenmesi amacı ile İsviçre'de üniversite öğrencileri üzerinde yapılan başka bir araştırmanın sonucuna göre, öğrencilerin sahip oldukları dışadönük kişilik özelliğinin sosyal ağ sitelerinin kullanımını etkilediği ve sosyal a $\breve{g}$ sitelerinin öğrencilerin birbirleri ile buluştukları ayrı bir ortam olduğu görüşü ortaya çıkmıştır (Wehrli, 2008).

Kullanıcıların kişilik özellikleri ile sosyal ağ sitelerini kullanım düzeyleri arasındaki ilişkinin belirlenmesi amacı ile Facebook ve Twitter kullanıcısı 300 kişi üzerinde yürütülen farklı bir çalışmanın sonucuna göre de, sosyal ağ sitelerinin sosyal etkileşim ve bilgi alışverişi açısından oldukça popüler bir araç haline geldiği sonucuna ulaşılmıştır. Facebook kullanıcılarının dışadönüklük ve duygusal denge puanlarının daha yükssek çıkması da elde edilen bir diğer bulgudur (Hughes ve diğerleri, 2012).

Girne Amerikan Üniversitesi Meslek Yüksekokulu'nda eğitim gören öğrencilerin sosyal medya kullanım alışkanlıklarının belirlenmesi ve internet kullanım sıklığı ile sosyal ağ kullanımı arasındaki ilişkinin saptanması amacı ile yürütülen bir başka araştırma sonucuna göre de; öğrencilerin gündemi takip etmek ve arkadaşları ile iletişim kurmak amacı ile sosyal ağ sitelerini kullandıkları görülmektedir. Araştırmaya katılan öğrencilerin en sık kullandığı sosyal ağların Whatsapp ve Facebook olduğu, internet kullanımının artmasına bağlı olarak sosyal medya kullanımının da yükseldiği ifade edilmektedir (Işıktaş, 2016).

Marmara Üniversitesi Teknik Bilimler Meslek Yüksekokulu'nda eğitim gören öğrencilerin sosyal ağ alışkanlıklarının belirlenmesi amacı ile yürütülen bir diğer araştırma sonucuna göre de; öğrencilerin tamamına yakınının aktif bir şekilde internet kullanımına sahip olduğu, çoğunlukla mobil cihazları tercih ettikleri, yaşıtları ile ilişki kurmak ve sosyalleşmek amacını taşıdıkları görülmektedir (Tektaş, 2014).

\section{Sonuç}

Teknoloji alanında yaşanan hızlı değişimler, internete erişim imkânının yükselmesi ve sosyal ağ sitelerinin özellikle günlük hayatın vazgeçilmezleri arasında yer alması gibi birtakım nedenlere bağlı olarak kullanım oranlarının da yükseldiği ifade edilmektedir. Literatür incelendiğinde özellikle gençlerin sahip oldukları kişilik özellikleri ile doğru orantılı olarak sosyal ağ sitelerini tercih ettikleri görülmektedir. Sosyal ağ sitelerinin daha çok sosyalleşmek, yeniliklere açık olmak ve iletişim kurmak amaçlı kullanımı ve uzun süre internette zaman geçirilmesi, eğitim amaçlı kullanımını azaltmakta ve buna bağlı olarak uzun vadede öğrenci başarısının da olumsuz yönde etkileneceği öngörülmektedir. $\mathrm{Bu}$ durum, konuya ilişkin bazı önlemlerin alınmasını da beraberinde getirmiştir. Bu amaçla;

- Öğrencilerin günlük hayattan kopmamaları ve eğitim alanındaki gelişmelerden haberdar olabilmeleri için de sosyal ağ sitelerini kullanmaları yönünde yönlendirilmelerinin,

- İnternette sosyalleşmek amacı ile geçirilen süreye ilişkin olarak zaman yönetimi açısından farkındalık yaratılmasının,

- Öğrencilerin eleştirel düşünme yeteneklerinin geliştirilmesine ve korunmasına yönelik olarak sosyal ă̆ sitelerinde eğitim amaçlı paylaşımların yaygınlaştırılmasına yönelik adımlar atılmasinin,

- Düzenlenecek seminerler ve grup çalışmaları ile sosyal ağ sitelerinin eğitim amaçlı kullanımı konusunda öğrencilerin bilinçlendirilmesinin faydalı sonuçlar doğuracağ d düşünülmektedir. 


\section{Kaynaklar}

ASLANYÜREK M., GÜRDAL S. A., DURSUN S., TUNÇEL E. ve AYAN S. M. İ. 2015. Sosyal medya gerçeği ve meslek yüksekokulu ögrencilerinin sosyal medya algısının değerlendirilmesi. Elektronic journal of vocational colleges Aralik, 1-8.

BILLEN, K., ERCAN, O. ve GÜLMEZ, T. 2014. Sosyal ağların kullanım amacı ve benimsenme süreci; Kahramanmaraş Sütçü İmam Üniversitesi Örneği. Eğitim ve öğretim araştırmaları dergisi, $3(1), 115-123$.

DAL, N. E. ve DAL, V. 2014. Kişilik özellikleri ve sosyal ağ sitesi kullanım alışkanlıkları: üniversite öğrencileri üzerine bir araştırma. Mehmet Akif Ersoy Üniversitesi sosyal bilimler enstitüsü dergisi, 6(11),144-162

DİKER, Z. ve UÇAR, M. 2017. Üniversite öğrencilerinin sosyal ağları kullanım amaçlarına yönelik bir araștırma: Safranbolu meslek yüksekokulu örneği. https://www.jret.org/FileUpload/ks281142/../38a..zeynep_diker.pdf (Erişim Tarihi: 09 Haziran 2017).

DILMEN, N. E., ÖĞÜT, S. Sosyalleşmenin yeni yüzü: sosyal paylaşım ağları. http://www.ocelott.com/documents/papers/sosyallesmenin-yeni-yuzu-sosyal-paylasim-aglari-ogutdilmen-tr.pdf. (Erişim Tarihi: 09 Haziran 2017).

GÜLBAHAR, Y., KALELIOĞLU, F. ve MARDAN, O. Sosyal ağların eğitim amaçlı kullanımı. inet-tr.org.tr/inetconf15/kitap/Y_Gulbahar_inet10.doc (Erişim Tarihi: 09 Haziran 2017).

HUGHES, D. J., ROWE, M., BATEY, M. \& LEE, A. 2012. A tale of two sites: Twitter vs. Facebook and the personality predictors of social media usage. Computers in human behavior, 28(2),561-569.

IŞIKTAŞ, S. 2016. Meslek yüksekokulu öğrencilerinin sosyal medya kullanımına yönelik tutumlarının değerlendirilmesi. ASOS akademik ve sosyal araştırmalar dergisi, 4(35),565-575.

KARAL, H. ve KOKOÇ, M. 2010. Üniversite öğrencilerinin sosyal ağ siteleri kullanım amaçlarını belirlemeye yönelik bir ölçek geliştirme çalışması. Turkish journal of computer and mathematics education, 1, 251-263.

KARLI, İ. 2010. Medya Kuruluşları Sosyal Paylaşım Ağlarını Neden Kullanır? http://akademikpersonel.kocaeli.edu.tr/ikarli/bildiri/ikarli18.06.2010_13.45.27bildiri.pdf $\quad$ (Erişim Tarihi: 09 Haziran 2017).

KAYA, H., TURAN, N., HASANOĞLU, Ö., GÜRE, Ö., ARSLANOVA, E. ve ELMAS, G. 2015. Hemşirelik fakültesi öğrencilerinin sosyal ağ sitelerini kullanma amacı ile iletişim becerileri arasındaki ilişkinin incelenmesi. İletişim kuram ve araştırma dergisi Gazi Üniversitesi iletişim fakültesi süreli elektronik dergi, 40,16-31.

ÖZDEMIR, S. S., ÖZDEMIR, M., POLAT, E. ve AKSOY, R. 2014. Sosyal medya kavramı ve sosyal ağ sitelerinde yer alan online reklam uygulamalarının incelenmesi. Electronic journal of vocational colleges. www.ejovoc.org/makaleler/aralik_2014/pdf/06.pdf (Erişim Tarihi:09 Haziran 2017).

SÖĞÜT, F., ÖZCAN, S. ve ASLAN, Y. 2016. Meslek yüksekokulu öğrencilerinin sosyal medya kullanımına yönelik tutumları. Erciyes iletişim dergisi akademia, 4(4),156-174.

SÜMER, N., SÜMER, H.C. (2005) Beş faktör kişilik özellikleri ölçeği (Yayınlanmamış çalışma).

TEKTAŞ, N. 2014. Üniversite öğrencilerinin sosyal ağları kullanımlarına yönelik bir araştırma. Tarih okulu dergisi, 7(17), 851-870.

WEHRLI, S. 2008. Personality on social network sites: an application of the five factor model. ETH Zurich sociology working paper, No:7. 
